\title{
Neglecting plant-microbe symbioses leads to underestimation of modeled climate impacts
}

\author{
Mingjie Shi ${ }^{1,2}$, Joshua B. Fisher ${ }^{1,2}$, Richard P. Phillips ${ }^{3}$, and Edward R. Brzostek ${ }^{4}$ \\ ${ }^{1}$ Jet Propulsion Laboratory, California Institute of Technology, 4800 Oak Grove Drive, Pasadena, CA 91109, USA \\ ${ }^{2}$ Joint Institute for Regional Earth System Science and Engineering, University of California at Los Angeles, \\ Los Angeles, CA 90095, USA \\ ${ }^{3}$ Department of Biology, Indiana University, 702 N. Walnut Grove Avenue, Bloomington, IN 47405, USA \\ ${ }^{4}$ Department of Biology, West Virginia University, 53 Campus Drive, Morgantown, WV 26506, USA
}

Correspondence: Edward R. Brzostek (erbrzostek@mail.wvu.edu)

Received: 18 June 2018 - Discussion started: 6 July 2018

Revised: 8 December 2018 - Accepted: 11 December 2018 - Published: 25 January 2019

\begin{abstract}
The extent to which terrestrial ecosystems slow climate change by sequestering carbon hinges in part on nutrient limitation. We used a coupled carbon-climate model that accounts for the carbon cost to plants of supporting nitrogen-acquiring microbial symbionts to explore how nitrogen limitation affects global climate. To do this, we first calculated the reduction in net primary production due to the carbon cost of nitrogen acquisition. We then used a climate model to estimate the impacts of the resulting increase in atmospheric $\mathrm{CO}_{2}$ on temperature and precipitation regimes. The carbon costs of supporting symbiotic nitrogen uptake reduced net primary production by $8.1 \mathrm{PgC}^{-1}$, with the largest absolute effects occurring in tropical forest biomes and the largest relative changes occurring in boreal and alpine biomes. Globally, our model predicted relatively small changes in climate due to the carbon cost of nitrogen acquisition with temperature increasing by $0.1^{\circ} \mathrm{C}$ and precipitation decreasing by $6 \mathrm{~mm} \mathrm{yr}^{-1}$. However, there were strong regional impacts, with the largest impact occurring in boreal and alpine ecosystems, where such costs were estimated to increase temperature by $1.0^{\circ} \mathrm{C}$ and precipitation by $9 \mathrm{~mm} \mathrm{yr}^{-1}$. As such, our results suggest that carbon expenditures to support nitrogen-acquiring microbial symbionts have critical consequences for Earth's climate, and that carbonclimate models that omit these processes will overpredict the land carbon sink and underpredict climate change.
\end{abstract}

Copyright statement. Mingjie Shi's and Joshua B. Fisher's copyright for this publication is transferred to the California Institute of Technology.

\section{Introduction}

The magnitude of carbon (C) uptake by the terrestrial biosphere strongly depends on the availability of nutrients to support net primary production (NPP) (Wang et al., 2010; Zaehle et al., 2015; Wieder et al., 2015). Most soil nutrients exist in unavailable forms and consequently plants must expend a portion of their assimilated $\mathrm{C}$ on nutrient acquisition (Johnson, 2010; Mohan et al., 2014). Many plants allocate up to $20 \%$ of their $\mathrm{C}$ to support symbiotic mycorrhizal fungi, which can be responsible for almost half of plant nitrogen (N) uptake in ecosystems (Hobbie, 2006; Högberg and Högberg, 2002; Parniske, 2008) or to support symbiotic N-fixing bacteria (Shi et al., 2016). Given the magnitude of these $\mathrm{C}$ expenditures, Earth system models (ESMs) that do not account for the costs of supporting symbiotic microbes may overestimate NPP and the ability of terrestrial ecosystems to slow climate change.

Nearly all land plants have evolved symbiotic strategies for coping with nutrient limitation. Plant associations with mycorrhizal fungi such as arbuscular mycorrhizae (AM) and ectomycorrhizae (ECM), or with N-fixers, are critical for the uptake of soil nutrients and, as such, impact $\mathrm{C}$ and nutrient cycling (Phillips et al., 2013; Wurzburger et al., 2017). Recent data syntheses have shown that ECM and AM ecosys- 
tems have divergent $\mathrm{C}$-nutrient economies that respond differently to elevated $\mathrm{CO}_{2}$ and $\mathrm{N}$ deposition (Canham and Murphy, 2017; Terrer et al., 2016, 2017). Despite this, the C cost for nutrient acquisition remains largely absent in most $\mathrm{C}-$ climate models which assume that plants do not expend $\mathrm{C}$ to take up N and that NPP is only downregulated if there is not enough $\mathrm{N}$ to support biomass synthesis. As such, there have been few first-order estimates of the extent to which variable plant investment in strategies that facilitate $\mathrm{N}$ uptake can impact rates of climate change. Shi et al. (2016) showed that dynamically predicting and accounting for the $\mathrm{C}$ cost of $\mathrm{N}$ acquisition reduced global NPP by $13 \%$, and, thus, models that assume $\mathrm{N}$ uptake requires no $\mathrm{C}$ expenditures potentially underestimate the rate of atmospheric $\mathrm{CO}_{2}$ rise. These results not only underscore the importance of including the $\mathrm{C}$ cost of symbiotic microbes in ESMs, but also highlight the critical role that plant-microbe interactions play in mediating rates of climate change.

Global C-climate models represent the scientific community's integrated hypotheses on how climate responds to anthropogenic forcing. In addition to forecasting climate, ESMs can be used to perform "experiments" at spatial and temporal scales that are logistically unfeasible to identify important feedbacks and processes in the Earth's climate system (Fisher et al., 2014). Accordingly, our objective was to explore the potential feedbacks between the $\mathrm{C}$ cost of supporting symbiotic $\mathrm{N}$ acquisition with climate by performing model experiments with and without these costs in a $\mathrm{C}-$ climate model. To streamline the complexity of the Earthscale computations, we used the Community Atmosphere Model (CAM) with prescribed sea surface temperatures and sea ice and a version of the Community Land Model (CLM) which predicts the impacts of symbiotic processes on coupled $\mathrm{C}$ and $\mathrm{N}$ dynamics. We are focusing on the dynamic processes between the land and atmosphere, and this $\mathrm{C}$-climate model assessment represents the first effort to determine the sensitivity of the Earth's climate system to plant-microbe symbiotic interactions.

\section{Material and methods}

\subsection{Models}

We used the Fixation and Uptake of Nitrogen (FUN) submodel to dynamically compute the $\mathrm{C}$ cost and $\mathrm{N}$ benefit of AM fungi, ECM fungi, and N-fixers. FUN optimally allocates the $\mathrm{C}$ gained from NPP to $\mathrm{N}$ acquisition through the following pathways: uptake from soil (via AM or ECM roots, or non-mycorrhizal roots), retranslocation from senescing leaves, and symbiotic biological $\mathrm{N}$ fixation (Brzostek et al., 2014; Fisher et al., 2010). FUN then downregulates NPP based upon the integrated $\mathrm{C}$ cost across each pathway and how much $\mathrm{N}$ was acquired to fix $\mathrm{C}$ into biomass. The $\mathrm{C}$ cost of each pathway is calculated using functions that relate costs to drivers with soil uptake a function of soil $\mathrm{N}$ concentration and root biomass, retranslocation a function of leaf $\mathrm{N}$, and fixation a function of temperature (Brzostek et al., 2014; Shi et al., 2016). In FUN, AM plants benefit when $\mathrm{N}$ is relatively abundant, ECM plants benefit when $\mathrm{N}$ is strongly limiting, and $\mathrm{N}$-fixers thrive in high energy environments with high $\mathrm{N}$ demand (Brzostek et al., 2014).

We used the Community Land Model version 4 (CLM) (Lawrence et al., 2011; Oleson et al., 2010). CLM is a terrestrial biosphere model that predicts the impacts of greenhouse gases and meteorological conditions on the land surface's energy, carbon, and water budgets. Importantly, CLM includes coupled $\mathrm{C}$ and $\mathrm{N}$ cycles whereby the internal recycling, loss, and inputs of $\mathrm{N}$ in the soil pool are dynamically modeled to predict the availability of $\mathrm{N}$ to support plant biomass synthesis (Lawrence et al., 2011; Oleson et al., 2010).

FUN was recently coupled into CLM (CLM-FUN) with model simulations showing that the $\mathrm{C}$ cost of $\mathrm{N}$ acquisition reduces the $\mathrm{C}$ sink strength of the terrestrial biosphere (Shi et al., 2016). CLM-FUN predicts the $\mathrm{C}$ cost of $\mathrm{N}$ acquisition from the soil by ectomycorrhizal, arbuscular mycorrhizal, and nonmycorrhizal roots based upon root biomass (a proxy for access) and soil nitrogen concentrations (a measure of availability of $\mathrm{N}$ for plants to take up). Previously, the parameter controlling the sensitivity of the $\mathrm{C}$ cost of $\mathrm{N}$ acquisition to root biomass was low. As such, the $\mathrm{C}$ cost of $\mathrm{N}$ acquisition showed little to no sensitivity to variability in root biomass across grid cells and the ECM cost of $\mathrm{N}$ acquisition was always lower than the AM cost of $\mathrm{N}$ acquisition even in high $\mathrm{N}$ biomes. We have updated this parameter so that the updated CLM-FUN is equally sensitive to both availability and access, and can better capture latitudinal gradients in the benefit of ECM uptake or AM uptake as $\mathrm{N}$ becomes more limiting. This adjustment also ensures that while ECM plants invest more $\mathrm{C}$ belowground, they get a greater return on this investment relative to AM-associated plants when the ratio of $\mathrm{N}$ needed to support NPP to available soil $\mathrm{N}$ increases (e.g., enhanced $\mathrm{N}$ limitation under elevated $\mathrm{CO}_{2}$ ) (Terrer et al., 2017). Specifically, we modified an AM-related uptake parameter and an ECM-related uptake parameter from $2.7 \times 10^{-4}$ to 6.2 $\left(\mathrm{g} \mathrm{C} \mathrm{m}^{-2}\right)$ and from $1.6 \times 10^{-3}$ to $34.1\left(\mathrm{~g} \mathrm{C} \mathrm{m}^{-2}\right)$, respectively (see Table $\mathrm{S} 1$ for original and updated parameters). This parameter adjustment also resulted in a small increase in the downregulation of NPP by FUN in CLM by $1.5 \mathrm{Pg} \mathrm{C} \mathrm{yr}^{-1}$ or $\sim 3 \%$ for the last 10 years of the model simulations from 1995 to 2004 (Fig. S1 in the Supplement). For this parameter adjustment, the spin-up, meteorological conditions, and time period are the same as outlined for CLM in Sect. 2.2 below.

To investigate the root symbiont associated $\mathrm{C}$-climate feedback, we also used Community Atmosphere Model version 4 (CAM), an atmospheric general circulation model that includes CLM (or CLM-FUN) (Neale et al., 2010). CAM dynamically predicts the impacts of external forcing factors such as anthropogenic $\mathrm{CO}_{2}$ emissions on global and regional climate (i.e., temperature and precipitation) by dy- 
namically representing key atmospheric processes, including cloud formation, aerosol impacts, radiative processes, and mixing (Neale et al., 2010).

\subsection{Experimental design}

In the first step of our model experiment, we leveraged the ability of FUN to downregulate NPP in order to calculate the extent to which mycorrhizal fungi impact the balance of $\mathrm{C}$ in the atmosphere vs. plant biomass. We estimated this by calculating the difference in NPP between CLM runs with FUN turned on or off using the same meteorological forcing data (Qian et al., 2006). The surface condition and plant functional type (PFT) data are from the standard release of CLM4.0. The surface spin-up conditions, in which the plant and soil $\mathrm{C}$ pools are at a quasi-equilibrium state, are provided with CLM4.0 by the National Center for Atmospheric Research (NCAR). As such, both models started from the same baseline values. We ran both CLM and CLM-FUN at the $0.9^{\circ} \times 1.25^{\circ}$ and half-hourly spatio-temporal resolution for 25 years (1980-2004). The ambient $\mathrm{CO}_{2}$ concentration was fixed to $338 \mathrm{ppm}$, the atmospheric $\mathrm{CO}_{2}$ level in 1980 . We calculated the mean annual NPP difference between CLM and CLM-FUN in 1995-2004, and the value was $8.1 \mathrm{Pg} \mathrm{C} \mathrm{yr}^{-1}$. This additionally respired $\mathrm{C}$ from CLM-FUN represents the $\mathrm{C}$ amount that plants expend to take up $\mathrm{N}$ and we assumed that all of this $\mathrm{C}$ went into the atmospheric pool. We then converted this mass of extra $\mathrm{C}$ going into the atmosphere into concentration units by dividing our mass $(8.1 \mathrm{PgC})$ by the mass of $\mathrm{C}$ in $1 \mathrm{ppm}$ of $\mathrm{CO}_{2}(2.135 \mathrm{PgC})$. As such, we assume that integrating the $\mathrm{C}$ costs for $\mathrm{N}$ acquisition leads to an additional $8.1 \mathrm{Pg} \mathrm{C} \mathrm{yr}^{-1}$ of $\mathrm{C}$ released into the atmosphere at a $3.8 \mathrm{ppm} \mathrm{CO}_{2}$ annual rate.

Second, we ran two simulations of the land-atmosphere model, CAM4.0-CLM 4.0: (1) a control simulation without mycorrhizal impacts on atmospheric $\mathrm{CO}_{2}$ or surface energy budgets (herein CAM), and (2) a simulation that included mycorrhizal impacts on atmospheric $\mathrm{CO}_{2}$ as well as surface energy budgets (herein CAM-FUN). Due to the complexity and computational cost of running the fully coupled $\mathrm{C}$-climate model, it was necessary to prescribe the increase in $\mathrm{CO}_{2}$ concentrations in CAM-FUN at a $3.8 \mathrm{ppm}$ increase per year to reflect the transfer of C from NPP to the atmosphere. The CAM runs did have dynamic representations of how the $\mathrm{C}$ cost of $\mathrm{N}$ acquisition impacted leaf area index (LAI), evapotranspiration (ET), and resulting energy budgets. We acknowledge that this assumption simplifies many of the interactions between the land, atmosphere, and ocean $\mathrm{C}$ pools. However, given that our objective was to provide a first approximation of how the $\mathrm{C}$ cost of $\mathrm{N}$ acquisition could impact climate, the prescribed $\mathrm{CO}_{2}$ increase provides a balance between meeting that objective and minimizing computational costs. We used the specified modern climatological sea surface temperatures and sea ice distributions and ran the models at the $0.9^{\circ} \times 1.25^{\circ}$ and half-hourly spatio- temporal resolution for 25 years from 1980 to 2004. In CAM, the ambient $\mathrm{CO}_{2}$ concentration was $338 \mathrm{ppm}$. For all other model inputs, we used the default input files that are automatically loaded during each model run, such that both CAM and CAM-FUN start off with the same initial conditions. In CAM-FUN, we assumed that atmospheric $\mathrm{CO}_{2}$ started increasing from $338 \mathrm{ppm}$ at the $3.8 \mathrm{ppm}$ of $\mathrm{CO}_{2}$ annual rate, and all the respired $\mathrm{CO}_{2}$ is mixed into the atmosphere homogenously. We also present the means of the CAM-based results for the last 10 simulation years from 1995 to 2004 . We evaluated the climate impacts resulting from including the mycorrhizal dynamics into CAM by calculating the surface air temperature and precipitation differences between CAM and CAM-FUN in different regions.

In this study, we also estimated the radiative forcing variations causing the climate impacts. We did this in order to identify which factor, ET vs. LAI vs. enhanced atmospheric $\mathrm{CO}_{2}$, led to our observed shifts in climate. It also allowed us to identify whether the three different forcing factors had a cooling or warming effect on the climate. We use the reflected solar radiation difference between CAM and CAMFUN to estimate the radiative forcing variations from surface albedo change due to shifts in LAI. The evapotranspiration (ET) difference between these two model runs was used to estimate the radiative forcing from ET variation. The radiative forcing from $\mathrm{CO}_{2}$ increase was calculated with an empirical equation (Myhre et al., 1998):

$$
\Delta F=\alpha \ln \left(\frac{C}{C_{0}}\right)
$$

where $\alpha$ is estimated as $5.35\left(\mathrm{~W} \mathrm{~m}^{-2}\right), C$ is $\mathrm{CO}_{2}$ in parts per million by volume, and $C_{0}$ is the reference concentration, which is $338 \mathrm{ppm}$, the atmospheric $\mathrm{CO}_{2}$ level in 1980 .

\section{Results}

Compared to the CAM runs where $\mathrm{N}$ was obtained at no cost, when we included the $\mathrm{C}$ cost of symbiont-mediated $\mathrm{N}$ acquisition (i.e., CAM-FUN), $\mathrm{C}$ uptake by the terrestrial biosphere was more strongly constrained by $\mathrm{N}$ availability. Consequently, N limitation reduced global NPP by $2.4 \mathrm{~g} \mathrm{C} \mathrm{m}^{-2} \mathrm{yr}^{-1}$, leading to alterations in atmospheric $\mathrm{CO}_{2}$, global leaf area index (LAI; Fig. 1a and b), and surface energy budgets (Fig. 2). Globally, NPP and LAI were affected similarly, with the strongest relative effects occurring at the poles and the strongest absolute effects occurring near the Equator. In addition, we analyzed temperature and precipitation shifts across three key biome classes that are delineated in Fig. S4. In boreal and alpine ecosystems, LAI was reduced by $34 \%$ (a decrease of $0.05 \mathrm{~m}^{2} \mathrm{~m}^{-2}$ ), while NPP was reduced by $42 \%$ (a decrease of $12 \mathrm{~g} \mathrm{C} \mathrm{m}^{-2} \mathrm{yr}^{-1}$ ). In midlatitude temperate ecosystems, LAI was reduced by $17 \%$ (a decrease of $0.16 \mathrm{~m}^{2} \mathrm{~m}^{-2}$ ), while NPP was reduced by $33 \%$ (a decrease of $30 \mathrm{~g} \mathrm{C} \mathrm{m}^{-2} \mathrm{yr}^{-1}$ ). Tropical forest ecosystems 

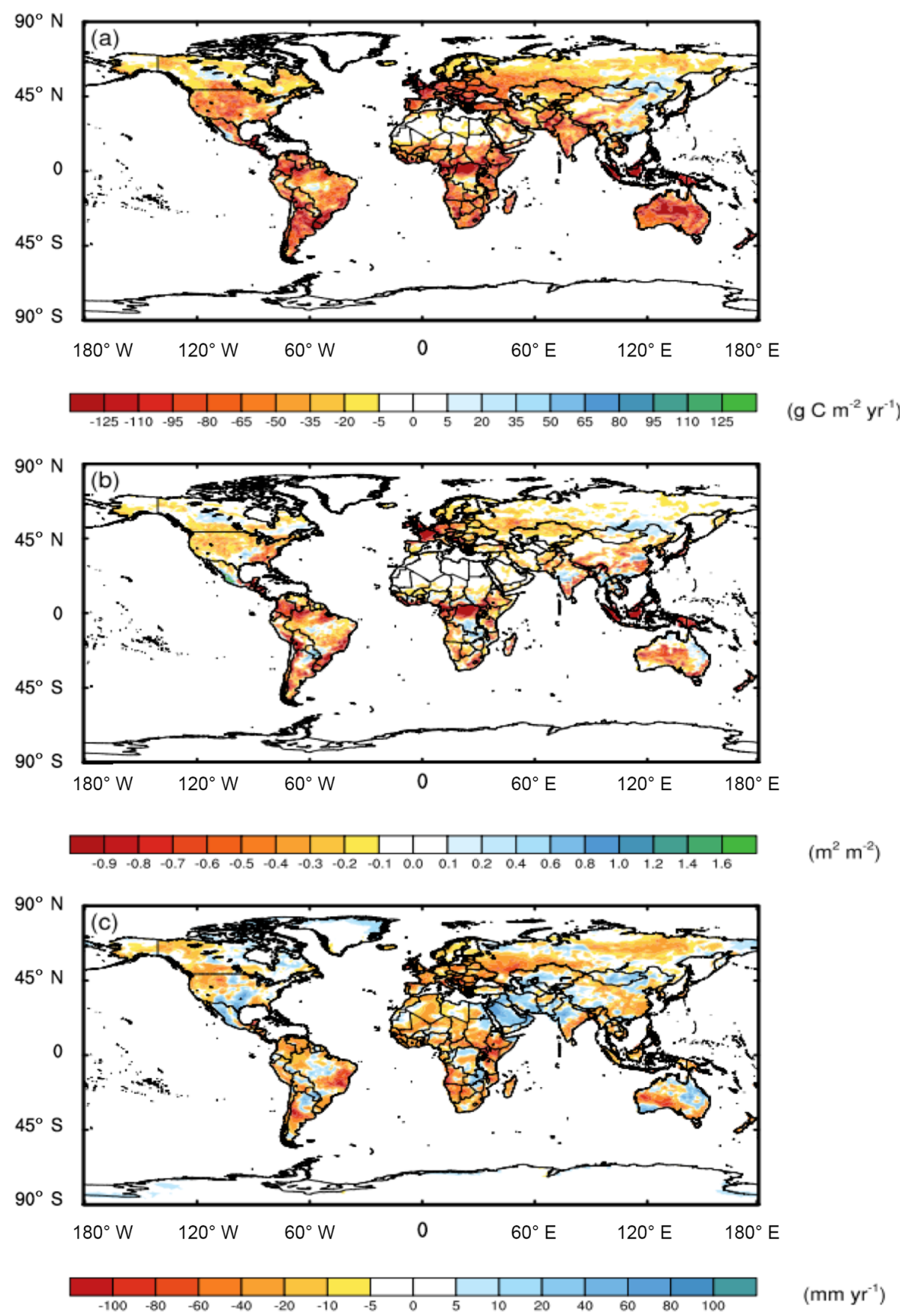

Figure 1. The $\mathrm{C}$ expended on symbiont-mediated $\mathrm{N}$ acquisition altered the spatial patterns of (a) NPP, (b) LAI, and (c) ET. These results were obtained from CAM runs with and without the symbiont sub-module (CLM-FUN) and represent the mean of the last 10 years of the simulation from 1995 to 2004.

had the largest absolute reductions in LAI $\left(0.24 \mathrm{~m}^{2} \mathrm{~m}^{-2}\right.$; $10 \%$ decrease) and NPP $\left(53 \mathrm{~g} \mathrm{C} \mathrm{m}^{-2} \mathrm{yr}^{-1} ; 22 \%\right.$ decrease). Compared to NPP and LAI, ET had a more heterogeneous spatial pattern with a global mean ET reduction of $7.3 \mathrm{~mm} \mathrm{yr}^{-1}$, which represents a $\sim 3 \%$ decrease across all of the ecosystems (Fig. 1c). While we present differences between model runs in LAI, ET, and NPP in Fig. 1, global maps of the absolute values are presented in Figs. S2 and S3.

Elevated $\mathrm{CO}_{2}$ due to the reduction in NPP was the strongest driver of climate shifts. The global NPP reduction $\left(8.1 \mathrm{Pg} \mathrm{C} \mathrm{yr}^{-1}\right)$ from the land model simulations resulted in an increase in atmospheric $\mathrm{CO}_{2}$ concentrations of $3.8 \mathrm{ppm} \mathrm{yr}^{-1}$, and $\sim 95 \mathrm{ppm}$ over a 25 -year simulation. Ac- 


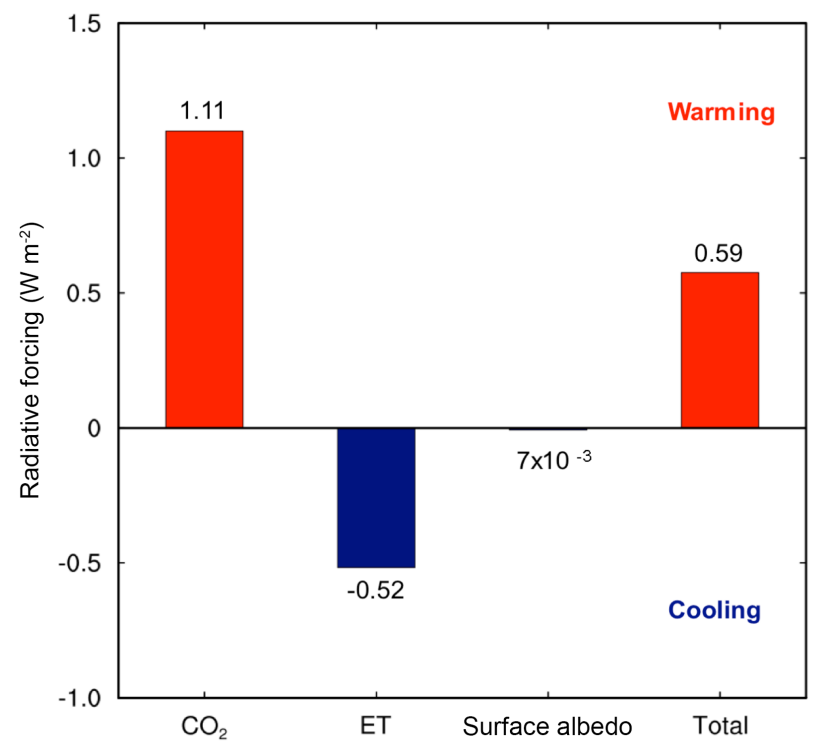

Figure 2. The impacts of the $\mathrm{C}$ cost of symbiont-mediated $\mathrm{N}$ acquisition led to a net increase in global radiative forcing. The warming due to increasing atmospheric $\mathrm{CO}_{2}$ was offset partially by cooling due to reduced evapotranspiration (ET) and surface albedo. These results were obtained from CAM runs with and without the symbiont sub-module (CLM-FUN) and represent the mean of the last 10 years of the simulation from 1995 to 2004 .

counting for the $\mathrm{C}$ cost of $\mathrm{N}$ acquisition in CAM's representation of $\mathrm{N}$ limitation led to a net warming effect of $1.11 \mathrm{~W} \mathrm{~m}^{-2}$ (Fig. 2). By contrast, there was an opposing effect of differences in LAI due to modifications of ET and surface albedo of the vegetated land surface, leading to an overall net cooling effect of $-0.52 \mathrm{~W} \mathrm{~m}^{-2}$ (Fig. 2). The reduction in ET led to a cooling effect because it resulted in less water vapor in the atmosphere, which is a potent greenhouse gas. Integrated globally, these two opposing effects led to a net warming effect of $0.59 \mathrm{~W} \mathrm{~m}^{-2}$ (Fig. 2), which resulted in a net increase in surface air temperature by $0.1^{\circ} \mathrm{C}$ and a net decrease in precipitation by $6 \mathrm{~mm} \mathrm{yr}^{-1}$, globally.

While the averaged global impact of the $\mathrm{C}$ cost of microbial symbionts on climate was minor (i.e., $0.1^{\circ} \mathrm{C}$ surface air temperature increase and $6 \mathrm{~mm} \mathrm{yr}^{-1}$ precipitation decrease), there were strong regional impacts in key biomes, particularly in forested regions with ECM fungi (Fig. 3). Moreover, the regional shifts in temperature were stronger than those of precipitation, with shifts in precipitation being much more variable and patchier than those of temperature (Fig. 3). Given difficulties in predicting regional precipitation as well as the high variability in our estimates, we present the data but acknowledge that these regional estimates are uncertain. ECM-dominated areas in boreal and alpine biomes became warmer (increases in surface air temperature by $1.0^{\circ} \mathrm{C}$ ) and wetter (increases in precipitation by $9 \mathrm{~mm} \mathrm{yr}^{-1}$ ). Temperate forest ecosystems, which include plants that possess all three nutrient acquisition strategies, were also impacted. The eastern part of North America, Europe, and China had surface air temperature increases of $0.5^{\circ} \mathrm{C}$, and precipitation shifted by $11,-37$, and $2 \mathrm{~mm} \mathrm{yr}^{-1}$ in these three regions, respectively. Tropical forests, which are dominated by AM fungi, were impacted less with temperature; the Amazon and Congo basins both had temperature increases of $\sim 0.3^{\circ} \mathrm{C}$. However, precipitation changes in tropical forests varied, with the Amazon and Congo basins drying by 4 and $49 \mathrm{~mm} \mathrm{yr}^{-1}$, respectively.

\section{Discussion and conclusions}

Here, we demonstrate that integrating the $\mathrm{C}$ cost of $\mathrm{N}$ acquisition into the formulation of $\mathrm{N}$ limitation in CAM reduced global NPP, LAI, and ET, with the greatest percentage decreases in boreal and alpine ecosystems (Fig. 1). These reductions led to substantial impacts on climate, particularly in boreal and alpine ecosystems where temperature increased by $1{ }^{\circ} \mathrm{C}$ and precipitation increased by $9 \mathrm{~mm} \mathrm{yr}^{-1}$ over the last 10 years of the simulations (1995-2004) (Fig. 3). It is important to note that the regional impacts of the $\mathrm{C}$ cost of $\mathrm{N}$ acquisition on temperature were much stronger than those on precipitation. These results suggest that by reducing $\mathrm{C}$ stored in woody biomass, the $\mathrm{C}$ transferred to symbionts leads to more atmospheric $\mathrm{CO}_{2}$ that would otherwise be locked up in vegetation (Fig. 2). This reduction in terrestrial productivity (Fig. 1a) and decrease in the terrestrial C sink in CAMFUN appears to alter the partitioning of energy fluxes at the land surface into sensible heat flux as well, which accelerates land-surface warming and intensified regional landatmosphere feedback (Jung et al., 2010). Collectively, these results suggest that the $\mathrm{C}$ cost of symbiont-mediated $\mathrm{N}$ acquisition is an important component of the Earth's climate system that has the potential to alter future climate trajectories.

The $\mathrm{C}$ expended by plants to support symbiont-mediated $\mathrm{N}$ uptake reduced the amount of $\mathrm{C}$ available to support leaf growth and, thus, reduced LAI. This global reduction in LAI (Fig. 1b) indirectly influenced climate through energy balance (i.e., albedo and ET) feedbacks (Buermann et al., 2001). It has been suggested that changes in the atmospheric heating pattern in the tropics as a result of the variations in latent heat flux may modify the Hadley circulation, which then can change the generation of waves along the polar front (Chase et al., 1996). As such, tropical LAI shifts (Fig. 1b) can potentially affect mid- and high-latitude climates and nearby ocean conditions through atmospheric teleconnections (Feddema et al., 2005), a possible explanation for the greater climate alterations we observed at high latitudes.

We found greater spatial heterogeneity in ET shifts than NPP or LAI shifts when we included the $\mathrm{C}$ cost of microbial symbionts in the model (Fig. 1). Some of this spatial variability may reflect the high sensitivity of ET to increases in atmospheric $\mathrm{CO}_{2}$ concentrations (Shi et al., 2013). More- 

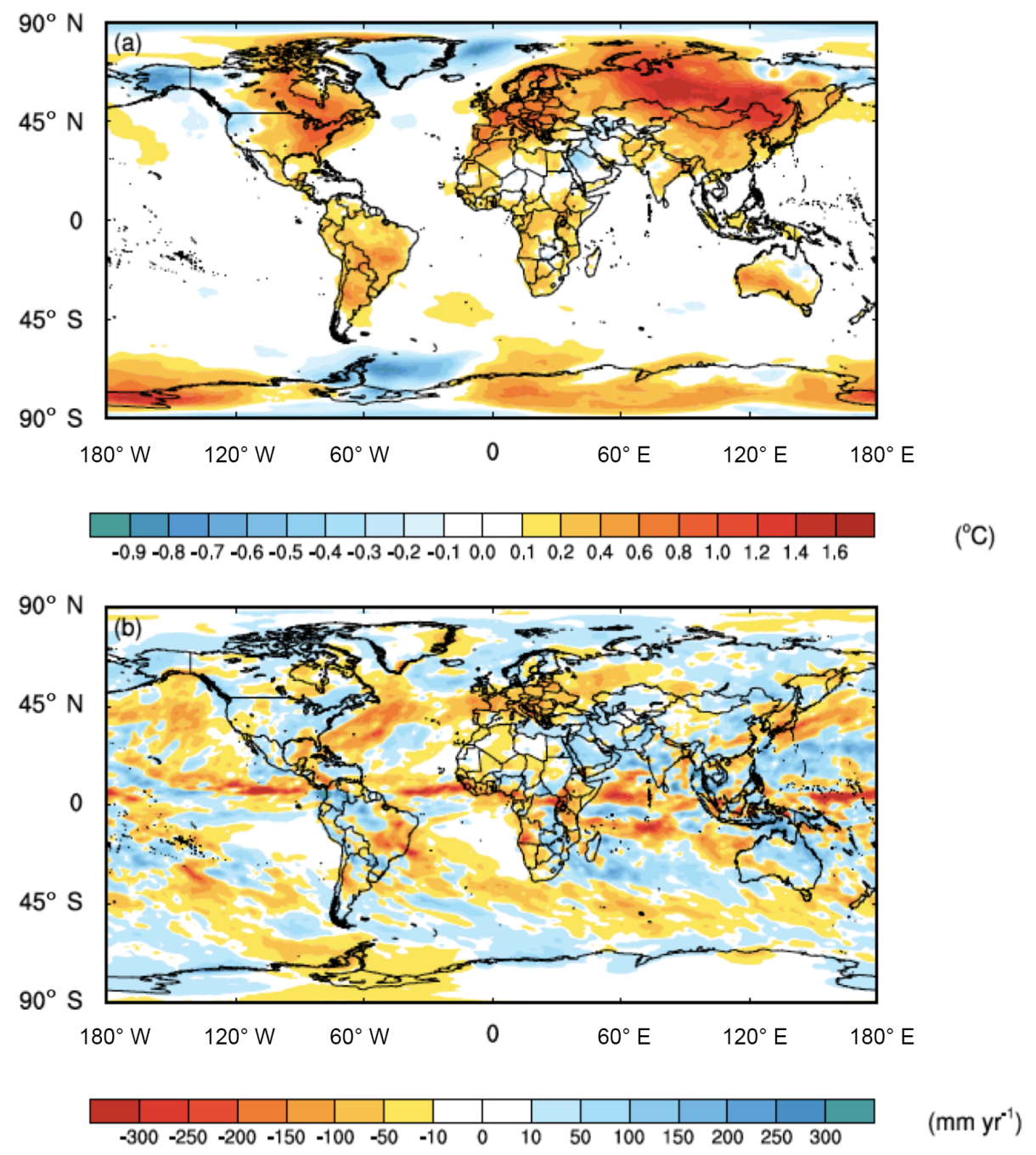

Figure 3. Feedbacks between symbiont-mediated $\mathrm{N}$ acquisition and $\mathrm{C}$ have a direct impact on global climate. (a) Surface air temperatures increase across much of the land surface, whereas (b) precipitation patterns are more variable. The values represent the mean differences for each grid cell between CAM-FUN with ramping $\mathrm{CO}_{2}$ and the baseline CAM for the last 10 years of the simulations from 1995 to 2004.

over, this variability likely reflects the large uncertainties and challenges associated with simulating regional-scale ET in coupled climate-atmosphere models (Boé and Terray, 2008; Pan et al., 2015). However, at the global scale, the reduction of ET, which decreased the atmospheric concentration of water vapor, a potent greenhouse gas, led to a $-0.52 \mathrm{~W} \mathrm{~m}^{-2}$ radiative forcing change (Fig. 2). This result is consistent with the Institut Pierre Simon Laplace climate model (IPSL-CM4) (Davin et al., 2007), where ET was also reduced globally and had a net cooling effect on global temperatures. Nevertheless, this cooling effect was outweighed by the warming effect of increasing atmospheric $\mathrm{CO}_{2}$ concentrations in CAM-FUN.

Our results suggest that models that do not account for plant-microbe symbiotic interactions and the $\mathrm{C}$ cost of $\mathrm{N}$ acquisition may underestimate both N limitation to NPP and rates of climate change. Nutrient limitation remains a key area of uncertainty for ESMs, with the CMIP5 comparison highlighting the limited representations of $\mathrm{N}$ limitation as a primary reason for mismatch between the models and the observed C sink (Anav et al., 2013). Additionally, CAM-FUN identifies an important underestimation of nutrient limitation and climate shifts in boreal and alpine ecosystems that has the potential to enhance other climate feedbacks. Boreal forests, which dominate high-latitude regions, are characterized by low rates of soil decomposition and low $\mathrm{N}$ availability (Read et al., 2004). This leads to CAM-FUN predicting that boreal forests will expend nearly $18 \%$ of NPP to gain $\mathrm{N}$ through symbionts, a result that is supported by a recent empirical synthesis which found that boreal forests have a 13-fold greater $\mathrm{C}$ cost of soil resource acquisition than tropical forests (Gill and Finzi, 2016). However, to the extent that the greater $\mathrm{C}$ cost to ECM plants (relative to AM plants) provides a greater return on investment of $\mathrm{N}$ under elevated $\mathrm{CO}_{2}$ (Terrer et al., 2017), some of the predicted warming may be 
attenuated over time. Nevertheless, predicted acceleration of warming in boreal forests is likely to be consequential given feedbacks between surface warming with sea ice cover loss, sea surface temperature increase, and permafrost thaw (Parmentier et al., 2013).

While CAM-FUN identifies an important interaction between the $\mathrm{C}$ cost of $\mathrm{N}$ limitation and climate, there still remain key uncertainties in the model on the extent to which other processes that govern the $\mathrm{C}$ cost of acquiring soil resources impacts $\mathrm{C}$-climate feedbacks. First, not all ecosystems are predominantly $\mathrm{N}$ limited (Wang et al., 2010). Nearly $30 \%$ of terrestrial ecosystems are limited by phosphorus $(\mathrm{P})$ or water (Elser et al., 2007; Fisher et al., 2012; Wieder et al., 2015). These are two key limitations that are currently absent from the model that may alter the climate trajectories shown here, particularly for strongly P-limited ecosystems like tropical forests or water-limited ecosystems like Mediterranean forests. However, FUN utilizes a modular structure based on optimal allocation theory that could incorporate the $\mathrm{C}$ costs of $\mathrm{P}$ or water acquisition on NPP and hence climate. As such, the optimal allocation parameterization in FUN could be modified to include other resource costs and thus provides a framework for ESMs to assess how multiple resource limitation impacts climate.

Second, the climate impacts we identify are sensitive to factors that alter $\mathrm{N}$ availability. Across many ecosystems, increasing soil temperatures that enhance decomposition (Melillo et al., 2011) or rising rates of $\mathrm{N}$ deposition in developing countries (Liu et al., 2013) could increase $\mathrm{N}$ availability and lower the $\mathrm{C}$ cost of $\mathrm{N}$ acquisition. Moreover, as currently formulated, the model omits important feedbacks between $\mathrm{C}$ allocation to mycorrhizal symbionts and their ability to upregulate soil enzyme production and prime soil organic matter decomposition and increase $\mathrm{N}$ availability (Brzostek et al., 2015; Cheng et al., 2014; Finzi et al., 2015). A recent effort to couple FUN to a microbial soil enzyme model at the ecosystem scale has shown that the ability of ECM fungi to prime soil organic matter allowed them to mine $\mathrm{N}$ at the expense of soil $\mathrm{C}$ stocks to a greater extent under elevated $\mathrm{CO}_{2}$ than AM fungi (Sulman et al., 2017). This result is consistent with recent meta-analyses that show that even though ECM plants invest more $\mathrm{C}$ belowground than AM plants, they receive a greater $\mathrm{N}$ return on their investment under elevated $\mathrm{CO}_{2}$ (Terrer et al., 2017). As such, integrating $\mathrm{C}$ and $\mathrm{N}$ feedbacks between plant and symbiotic microbes at the global scale represents a critical area for future model development.

Finally, we acknowledge that the simplification of landatmosphere interactions in our model experiment may have precluded our ability to examine fully coupled feedbacks that may have stimulated the land or ocean $\mathrm{C}$ sink. This simplification was needed owing to the complexity and computational resources needed to run the fully coupled model. As such, our estimates of the sensitivity of climate to the $\mathrm{C}$ cost of $\mathrm{N}$ acquisition likely represents an upper bound. This is due to three reasons. First, we assumed that all of the carbon not sequestered as NPP was released into the atmosphere as $\mathrm{CO}_{2}$. In a fully coupled model, it is likely that a portion of this $\mathrm{CO}_{2}$ would have been sequestered by the ocean. Second, the reduction of NPP due to the $\mathrm{C}$ cost of $\mathrm{N}$ acquisition also reduced heterotrophic respiration by $3.3 \mathrm{Pg} \mathrm{C} \mathrm{yr}^{-1}$. However, both empirical and modeling evidence suggests that $\mathrm{C}$ expended belowground to gain $\mathrm{N}$ leads to greater soil organic matter decomposition and respiration due to priming effects (Brzostek et al., 2015; Sulman et al., 2017). Lastly, compared to other ESMs included in the Fifth Phase of the Coupled Model Intercomparison Project (CMIP5), the land C pool in CESM/CLM4 is underestimated (Hoffman et al., 2014), associated with a high-biased $\mathrm{N}$ downregulation and short turnover times for decomposing C (Koven et al., 2013). This low-biased land $\mathrm{C}$ pool indicates an overestimation of the atmospheric $\mathrm{CO}_{2}$ burden over the 20th century (Hoffman et al., 2014). Despite our assumptions, experimental design, and bias impacting the model's ability to predict absolute numbers, our modeling experiments allowed us to make the first test of the sensitivity of the Earth's climate system to plantmicrobial interactions.

To fully integrate the $\mathrm{C}$ cost of multiple soil resource acquisition into ESMs, there are key empirical gaps that still need to be addressed, including advancing observational datasets of the distribution of nutrient acquisition strategies at the global scale and expanding the spatial coverage and enhancing the temporal resolutions of both in situ and remote sensing data that can better parameterize the $\mathrm{C}$ cost of nutrient acquisition as well as the $\mathrm{N}$ benefit of microbial symbionts (Fisher et al., 2016). This study shows that highlatitude regions with low $\mathrm{N}$ available are more impacted by $\mathrm{C}$ cost of $\mathrm{N}$ acquisition. However, remote sensing observations are limited in high-latitude regions as a result of the long snow-cover season and cloud contamination. Thus, in situ and aircraft data can potentially provide more accurate information in high-latitude regions. Given that the next version of CESM will include the optimal allocation theory of FUN, addressing these empirical and modeling gaps will aid in reducing uncertainty in the extent to which nutrient limitation drives $\mathrm{C}$-climate feedbacks.

Code and data availability. The data for all three figures as well as the model code are available at https://github.com/coffeesmj/ Biogeosciences-Submission.git (Shi et al., 2019).

Supplement. The supplement related to this article is available online at: https://doi.org/10.5194/bg-16-457-2019-supplement.

Author contributions. MS and ERB designed the research; MS conducted the model simulations and performed the analyses; ERB and JBF contributed essential ideas of analyzing the results; ERB and MS wrote the manuscript with contributions from JBF and RPP. 
Competing interests. The authors declare that they have no conflict of interest.

Acknowledgements. Funding was provided by the US Department of Energy (Office of Biological and Environmental Research, Terrestrial Ecosystem Science Program) and the US National Science Foundation (Division of Environmental Biology, Ecosystem Studies Program). The computations were performed at the Jet Propulsion Laboratory and at the National Aeronautics and Space Administration (NASA) Ames Research Center. Junjie Liu assisted with the computational resources. Mingjie Shi and Joshua B. Fisher carried out the research at the Jet Propulsion Laboratory, California Institute of Technology, under a contract with NASA, and at the Joint Institute for Regional Earth System Science and Engineering, University of California at Los Angeles. Government sponsorship acknowledged.

Edited by: Anja Rammig

Reviewed by: two anonymous referees

\section{References}

Anav, A., Friedlingstein, P., Kidston, M., Bopp, L., Ciais, P., Cox, P., Jones, C., Jung, M., Myneni, R., and Zhu, Z.: Evaluating the Land and Ocean Components of the Global Carbon Cycle in the CMIP5 Earth System Models, J. Climate, 26, 6801-6843, 2013.

Boé, J. and Terray, L.: Uncertainties in summer evapotranspiration changes over Europe and implications for regional climate change, Geophys. Res. Lett., 35, L05702, https://doi.org/10.1029/2007GL032417, 2008.

Brzostek, E. R., Fisher, J. B., and Phillips, R. P.: Modeling the carbon cost of plant nitrogen acquisition: Mycorrhizal tradeoffs and multipath resistance uptake improve predictions of retranslocation, J. Geophys. Res.-Biogeo., 119, 1684-1697, https://doi.org/10.1002/2014JG002660, 2014.

Brzostek, E. R., Dragoni, D., Brown, Z. A., and Phillips, R. P.: Mycorrhizal type determines the magnitude and direction of rootinduced changes in decomposition in a temperate forest, New Phytol., 206, 1274-1282, 2015.

Buermann, W., Dong, J., Zeng, X., Myneni, R. B., and Dickinson, R. E.: Evaluation of the Utility of Satellite-Based Vegetation Leaf Area Index Data for Climate Simulations, J. Climate, 14, 35363550, 2001.

Canham, C. D. and Murphy, L.: The demography of tree species response to climate: sapling and canopy tree survival, Ecosphere, 8, e01701, https://doi.org/10.1002/ecs2.1701, 2017.

Chase, T. N., Pielke, R. A., Kittel, T. G., Nemani, R., and Running, S. W.: Sensitivity of a general circulation model to global changes in leaf area index, J. Geophys. Res.-Atmos., 101, 73937408, 1996.

Cheng, W., Parton, W. J,. Gonzalez-Meler, M. A., Phillips, R. P., Asao, S., McNickle, G. G., Brzostek, E. R., and Jastrow, J. D.: Synthesis and modeling perspectives of rhizosphere priming, New Phytol., 201, 31-44, 2014.

Davin, E. L., De Noblet-Ducoudré, N., and Friedlingstein, P.: Impact of land cover change on surface climate: Relevance of the radiative forcing concept, Geophys. Res. Lett., 34, L13702, https://doi.org/10.1029/2007GL029678, 2007.

Elser, J. J., Bracken, M. E. S., Cleland, E. E., Cruner, D. S., Harpole, W. S., Hillebrand, H., Ngai, J. T., Seabloom, E. W., Shurin, J. B., and Smith, J. E.: Global analysis of nitrogen and phosphorus limitation of primary producers in freshwater, marine and terrestrial ecosystem, Ecol. Lett., 10, 1135-1142, 2007.

Feddema, J. J., Oleson, K. W., Bonan, G. B., Mearns, L. O., Buja, L. E., Meehl, G. A., and Washington, W. M.: The importance of land-cover change in simulating future climates, Science, 310, 1674-1678, 2005.

Finzi, A. C., Abramoff, R. Z., Spiller, K. S., Brzostek, E. R., Darby, B. A., Kramer, M. A., and Phillips, R. P.: Rhizosphere processes are quantitatively important components of terrestrial carbon and nutrient cycles, Glob. Change Biol., 21, 2082-2094, 2015.

Fisher, J. B., Sitch, S., Malhi, Y., Fisher, R. A., Huntingford, C., and Tan, S. Y.: Carbon cost of plant nitrogen acquisition: A mechanistic, globally applicable model of plant nitrogen uptake, retranslocation, and fixation, Global Biogeochem. Cy., 24, GB1014, https://doi.org/10.1029/2009GB003621, 2010.

Fisher, J. B., Badgley, G., and Blyth, E.: Global nutrient limitation in terrestrial vegetation, Global Biogeochem. Cy., 26, GB3007, https://doi.org/10.1029/2011GB004252, 2012.

Fisher, J. B., Huntzinger, D. N., Schwalm, C. R., and Sitch, S.: Modeling the Terrestrial Biosphere, Annu. Rev. Env. Resour., 39, 91 123, 2014.

Fisher, J. B., Sweeney, S., Brzostek, E. R., Evans, T. P., Johnson, D. J., Myers, J. A., Bourg, N. A., Wolf, A. T., Howe, R. W., and Phillips, R. P.: Tree-mycorrhizal associations detected remotely from canopy spectral properties, Glob. Change Biol., 22, 25962607, 2016.

Gill, A. L. and Finzi, A. C.: Belowground carbon flux links biogeochemical cycles and resource-use efficiency at the global scale, Ecol Lett., 19, 1419-1428, 2016.

Hobbie, E. A.: Carbon allocation to ectomycorrhizal fungi correlates with belowground allocation in culture studies, Ecology, 87, 563-569, 2006.

Hoffman, F. M., Randerson, J. T., Arora, V. K., Bao, Q., Cadule, P., Ji, D., Jones, C. D., Kawamiya, M., Khatiwala, S., Lindsay, K., Obata, E., Six, K. D., Tjiputra, J. F., Volodin, E. M., and Wu, T: Causes and implications of persistent atmospheric carbon dioxide biases in Earth System Models, J. Geophys. Res.-Biogeo., 119, 141-162, 2014.

Högberg, M. N. and Högberg, P.: Extramatrical ectomycorrhizal mycelium contributes one-third of microbial biomass and produces, together with associated roots, half the dissolved organic carbon in a forest soil, New Phytol., 154, 791-795, 2002.

Johnson, N. C.: Resource stoichiometry elucidates the structure and function of arbuscular mycorrhizas across scales, New Phytol., 185, 631-647, 2010.

Jung, M., Reichstein, M., Ciais, P., Seneviratne, S. I., Sheffield, J., Goulden M. L., Bonan, G., Cescatti, A., Chen, J., de Jeu, R., Dolman, J., Eugster, W., Gerten, D., Gianelle, D., Gianelle, D., Gobron, N., Heinke, J., Kimball, J., Law, B. E., Montagnani, L., Mu, Q., Muller, B., Oleson, K., Papale, D., Richardson, A. D., Roupsard, O., Running, S., Tomelleri, E., Viovy, N., Weber, U., Williams, C., Wood, E., Zaehle, S., and Zhang, K.: Recent decline in the global land evapotranspiration trend due to limited moisture supply, Nature, 467, 951-954, 2010. 
Koven, C. D., Riley, W. J., Subin, Z. M., Tang, J. Y., Torn, M. S., Collins, W. D., Bonan, G. B., Lawrence, D. M., and Swenson, S. C.: The effect of vertically resolved soil biogeochemistry and alternate soil $\mathrm{C}$ and $\mathrm{N}$ models on C dynamics of CLM4, Biogeosciences, 10, 7109-7131, https://doi.org/10.5194/bg-107109-2013, 2013.

Lawrence, D. M., Oleson, K. W., Flanner, M. G., Thornton, P. E., Swenson, S. C., Lawrence, P. J., Zeng, X., Yang, Z.-L., Levis, S., Sakaguchi, K., Bonan, G. B., and Slater, A. G.: Parameterization improvements and functional and structural advances in Version 4 of the Community Land Model, J. Adv. Model. Earth Sy., 3, M03001, https://doi.org/10.1029/2011MS00045, 2011.

Liu, X., Zhang, Y., Han, W., Tang, A., Shen, J., Cui, Z., Vitousek, P., Erisman, J. W., Goulding, K., Christie, P., Pangmeier, A., and Zhang, F.: Enhanced nitrogen deposition over China, Nature, 494, 459-462, 2013.

Melillo, J. M., Butler, S., Johnson, J., Mohan, J., Steudier, P., Lux, H., Burrows, E., Bowies, F., Smith, R., Scott, L., Vario, C., Hill, T., Burton, A., Zhou, Y.-M., and Tang, J.: Soil warming, carbonnitrogen interactions, and forest carbon budgets, P. Natl. Acad. Sci. USA, 108, 9508-9512, 2011.

Mohan, J. E., Cowden, C. C., Baas, P., Dawadi, A., Frankson, P. T., Helmick, K., Hughes, H., Khan, S., Lang, A., Machmuller, M., Taylor, M., and Witt, C. A.: Mycorrhizal fungi mediation of terrestrial ecosystem responses to global change: mini-review, Fungal Ecol., 10, 3-19, 2014.

Myhre, G., Highwood, E. J., Shine, K. P., and Stordal, F.: New estimates of radiative forcing due to well mixed greenhouse gases, Geophys. Res. Lett., 25, 2715-2718, 1998.

Neale, R. B., Gettelman, A., Park, S., Conley, A. J., Kinnison D., Marsh, D., Smith, A. K., Vitt, F., Morrison, H., Cameron-Smith, P., Collins, W. D., Iacono, M. J., Easter, R. C., Ghan, S. J., Liu, X., Rasch, P. J., and Taylor, M. A.: Description of the NCAR community atmosphere model (CAM 5.0), NCAR Tech. Note NCAR/TN-486+ STR, 2010.

Oleson, K. W., Lawrence, D. M., Bonan, G. B., Flanner, M. G., Kluzek, E., and Lawrence, P. J.: Technical description of version 4.0 of the Community Land Model, NCAR Tech. Note, NCAR/TN-478+STR, 2010.

Pan, S., Tian, H., Dangal, S. R. S., Yang, Q., Yang, J., Lu, C., Tao, B., Ren, W., and Ouyang, Z.: Responses of global terrestrial evapotranspiration to climate change and increasing atmospheric $\mathrm{CO}_{2}$ in the 21st century, Earths Future, 3, 15-35, 2015.

Parmentier, F.-J. W., Christensen, T. R., Sorensen, L. L., Rysgaard, S., Mcguire, A. D., Miller, P. A., and Walker, D. A.: The impact of lower sea-ice extent on Arctic greenhouse-gas exchange, Nat. Clim. Change, 3, 195-202, 2013.

Parniske, M.: Arbuscular mycorrhiza: the mother of plant root endosymbioses, Nat. Rev. Micro., 6, 763-775, 2008.

Phillips, R. P., Brzostek, E. R., and Midgley, M. G.: The mycorrhizal-associated nutrient economy: a new framework for predicting carbon-nutrient couplings in temperate forests, New Phytol., 199, 41-51, 2013.
Qian, T., Dai, A., Trenberth, K. E., and Oleson, K. W.: Simulation of global land surface conditions from 1948 to 2004. Part I: Forcing data and evaluations, J. Hydrometeorol., 7, 953-975, 2006.

Read, D. J., Leake, J. R., and Perez-Moreno, J.: Mycorrhizal fungi as drivers of ecosystem processes in heathland and boreal forest biomes, Can. J. Botany 82, 1243-1263, 2004.

Shi, M., Fisher, J. B., Brzostek, E. R., and Phillips, R. P.: Carbon cost of plant nitrogen acquisition: global carbon cycle impact from an improved plant nitrogen cycle in the Community Land Model, Glob. Change Biol., 22, 1299-1314, 2016.

Shi, X., Mao, J., Thornton, P. E., and Huang, M.: Spatiotemporal patterns of evapotranspiration in response to multiple environmental factors simulated by the Community Land Model, Environ. Res. Lett., 8, 024012, https://doi.org/10.1088/17489326/8/2/024012, 2013.

Shi, M., Fisher, J. B., Phillips, R. P., and Brzostek, E. R.: CAM and CLM-FUN code and Figure Data for Shi et al. 2019 Biogeosciences, available at: https://github.com/coffeesmj/ Biogeosciences-Submission.git, last access: 22 January 2019.

Sulman, B. N., Brzostek, E. R., Medici, C., Shevliakova, E., Menge, D. N., and Phillips, R. P.: Feedbacks between plant N demand and rhizosphere priming depend on type of mycorrhizal association, Ecol. Lett., 20, 1043-1053, 2017.

Terrer, C., Vicca, S., Hungate, B. A., Phillips, R. P., and Prentice, I. C.: Mycorrhizal association as a primary control of the $\mathrm{CO}_{2}$ fertilization effect, Science, 353, 72-74, 2016.

Terrer, C., Vicca, S., Stocker, B. D., Hungate, B. A., Phillips, R. P., Reich, P. B., Finzi, A. C., and Prentice, I. C.: Ecosystem responses to elevated $\mathrm{CO}_{2}$ governed by plant-soil interactions and the cost of nitrogen acquisition, New Phytol., 217, 507-522, 2017.

Wang, Y. P., Law, R. M., and Pak, B.: A global model of carbon, nitrogen and phosphorus cycles for the terrestrial biosphere, Biogeosciences, 7, 2261-2282, https://doi.org/10.5194/bg-7-22612010, 2010.

Wieder, W. R., Cleveland, C. C., Smith, W. K., and Todd-Brown, K.: Future productivity and carbon storage limited by terrestrial nutrient availability, Nature Geosci., 8, 441-444, 2015.

Wurzburger, N., Brookshire, E. N. J, Mccormack, M. L., and Lankau, R. A.: Mycorrhizal fungi as drivers and modulators of terrestrial ecosystem processes, New Phytol., 213, 996-999, 2017.

Zaehle, S., Jones, C. D., Houlton, B., Lamarque, J. F., and Robertson, E.: Nitrogen Availability Reduces CMIP5 Projections of Twenty-First-Century Land Carbon Uptake, J. Climate, 28, 2494-2511, 2015. 